\title{
Cell-division pattern and phylogenetic position of a new ciliate genus Parasincirra n. g. (Protista, Ciliophora, Hypotrichia), with report of a new soil species, P. sinica n. sp. found from northwest China
}

Jiyang Ma

Ocean University of China

Yan Zhao

Capital Normal University

Tengyue Zhang

Ocean University of China

Chen Shao ( $\nabla$ shaochen@snnu.edu.cn )

Xi'an Jiaotong University https://orcid.org/0000-0001-8474-3204

Khaled A.S. Al-Rasheid

King Saud University

Weibo Song

Ocean University of China

Research article

Keywords: New species, Morphology, Morphogenesis, Parasincirra, SSU rDNA phylogeny

Posted Date: December 16th, 2019

DOI: https://doi.org/10.21203/rs.2.17534/v2

License: (c) (i) This work is licensed under a Creative Commons Attribution 4.0 International License.

Read Full License 


\section{Abstract}

Ciliated species, unicellular eukaryotes, are extremely diverse and occupy a very broad spectrum of ecological niches. Even though there is a growing recognition that enormous ciliates associates with key ecosystem processes in different niches, their diversity is not well understood. One reason is that ciliates are very tiny and may often be overlooked in routine biodiversity survey. Furthermore, the morphological and genetic diversity of ciliates per se is vast and dwarfs that among other multicellular eukaryotes. Here, we present the study of a new stichotrichid ciliate, Parasincirra sinica n. g., n. sp. based on classical living morphology, infraciliature, ontogenesis analyses and a comprehensive phylogenetic study, and enhance understanding of ciliates diversity in sludge soil. This new, monotypic genus is defined by having a bipartite adoral zone of membranelles, three frontal cirri, an amphisiellid median cirral row about as long as, or slightly longer than, the adoral zone, one short frontoventral cirral row, cirrus III/2 and transverse cirri present, buccal cirrus and caudal cirri absent, three dorsal kineties. The main morphogenetic features are: (1) five frontoventral-transverse cirral anlagen (excluding undulating membranes anlage) are formed in primary mode; (2) the amphisiellid median cirral row is formed by anlagen $\mathrm{V}$ and $\mathrm{VI}$, while the frontoventral row is generated from anlage IV; (3) cirral streaks IV to VI generate one transverse cirrus each; (4) frontoventral-transverse cirral anlage II generates one or two cirri, while the posterior one will be absorbed in late stages, that is, no buccal cirrus is formed; (5) the posterior part of the parental adoral zone of membranelles is renewed; (6) dorsal morphogenesis follows a typical Gonostomum -pattern. Based on the SSU rDNA information, analyses of the phylogenetic relationship inferred from Bayesian inference and maximum likelihood analyses were unable to outline the exact position of this new form among some other species of related genera which are generally assigned in the family Amphisiellida. The morphological/ morphogenetical differences between the new genus/species and Uroleptoides / Parabistichella , as well as other amphisiellids, clearly support the validity of the establishment of this new genus Parasincirra .

\section{Background}

Ciliates are extremely diverse and occupy almost all environments. They are important grazers of algae, bacteria, and other microorganisms and transfer nutrients to other multicellular organisms and therefore play key ecosystem processes in different niches. And with characteristic of unique nucleus patterns, the studies of ciliates become prevalent model in ecological, evolutionary and genetic studies [1-8]. However, the above works are seriously limited by insufficient understanding of the global diversity of ciliates. The reasons that hamper the estimation of ciliates biodiversity is that ciliates are very tiny and their species identification is a difficult task. Furthermore, the morphological and genetic diversity of ciliates per se is vast and makes biodiversity survey becomes a daunting challenge.

As the most diverse linages of ciliates, the subclass Hypotrichia Stein, 1859 has been the subject of much research. A consistent focus in that research has been the use of silver staining methods to reveal species characteristics that are important for taxonomic classification and for determining the morphogenetic processes, as well as the use of molecular technologies to reveal their evolutionary 
relationships [9-25]. And even so, overall previous findings failed to recover the monophyly of Hypotrichia and the classification, validity, delimitation and phylogenetic relationships among and within these groups remains problematic $[26,27]$.

Among these, the order Stichotrichida is one of the most confused and diverse ciliate groups both in taxonomy and phylogeny [28]. One of its largest members, Amphisiellidae, is characterised by possessing an amphisiellid median cirral row derived from two or three frontoventral-transverse cirral anlagen and represents a species-rich family. Most amphisiellid species are known to occur in terrestrial habitats, although some are marine $[4,29,30]$. In the present study, we present a new species in this family collected from sludge soil in a flood drain in Lanzhou, China. Observations of its morphology and morphogenesis, both in vivo and after protargol staining, demonstrate that it represents a novel genus,

Parasincirra n. g. of the family Amphisiellidae. The SSU rDNA of the new isolate was sequenced and the based phylogenetic studies were also investigated. The results show that the new species living in the sludge niche have diverged from its related congeners and we suppose that it might undergo a characteristic evolutionary adaptation and represent novel metabolic functions

\section{Results}

\section{Taxonomy}

\section{Order Stichotrichida Fauré-Fremiet, 1961}

\section{Family Amphisiellidae Jankowski, 1979}

\section{Parasincirra n. g.}

Diagnosis. Amphisiellidae with very elongate elliptical body. Adoral zone of membranelles interrupted by an inconspicuous gap. Three frontal cirri. Amphisiellid median cirral row about as long as, or slightly longer than, adoral zone of membranelles. One short frontoventral cirral row. Cirrus III/2 and transverse cirri present. One right and one left marginal row. Three dorsal kineties. Caudal cirri and buccal cirrus lacking.

Etymology. Composite of the Greek prefix para-(close to; related; deviating) and the posterior part (sincirra) of the genus name Hemisincirra. This indicates that Parasincirra has a cirral pattern similar to the Hemisincirra. This similarity should indicate a relationship to Hemisincirra, but whereas the new genus lacks a buccal cirrus Hemisincirra possesses one. Like Hemisincirra, Parasincirra has a feminine gender.

Species assignable. Parasincirra sinica n. sp. (type species).

Remarks. We do not assign Hemisincirra interrupta and $H$. vermicularis to Parasincirra although these two species also lack a buccal cirrus and possess a bipartite adoral zone of membranelles. Ontogenetic 
data and gene sequence analyses are needed for a better interpretation of these features as well as to show whether or not the three species preliminarily included cluster together.

\section{Morphological description of Parasincirra sinica n. sp. (Fig. 2a-l; Table 1)}

Diagnosis. Size in vivo 90-160 × 20-40 um. Body usually slender, almost fusiform to worm-shaped, with posterior end more or less tapered to form a short tail. Contractile vacuole about $13 \mu \mathrm{m}$ across, located slightly ahead of mid-body, near the left cell margin. Cortical granules colourless and usually arranged around dorsal ciliary organelles, about $0.5 \mu \mathrm{m}$ across. Adoral zone of membranelles bipartite, composed of 14-19 adoral membranelles in total. Amphisiellid median cirral row terminates behind the buccal vertex, composed of four cirri. Three slightly enlarged frontal cirri, one parabuccal cirrus, frontoventral row consistently composed of two cirri, and two to four transverse cirri. Usually one left and one right marginal row, composed of 34-52 and 34-53 cirri respectively. Three bipolar dorsal kineties. Two to six macronuclear nodules. Soil habitat.

Type locality. Flood drain, Lanzhou $\left(36^{\circ} 03^{\prime} \mathrm{N} ; 103^{\circ} 49^{\prime} \mathrm{E}\right)$, northwest China.

Etymology. The species-group name sinica means the species was first discovered in China.

Morphological description. The body colourless to greyish in colour, non-contractile but highly flexible, and thus cell outline variable, i.e., sigmoidal or curved (Fig. 2d). Generally slender, almost fusiform to worm-shaped. Anterior end narrowly rounded and posterior end more or less tapered to form a short tail that is more flexible and contractile than the rest of the cell, and unrecognisable in protargol preparations (Fig. 2a, g-j). Dorsoventrally flattened up to 2:1. Cells were $90-160 \times 20-40 \mu \mathrm{m}$ in living cells ( $n=6)$, with an average of $120 \times 30 \mu \mathrm{m}$ in prepared cells, with a ratio of length to width of about 3.5:1-7.5:1 in vivo and on average 4:1 in protargol preparations. Two to six macronuclear nodules usually arranged along mid-line, or slightly left of it, behind buccal vertex and one to three, on average two, micronuclei attached, or near to, macronuclear nodules. Macronuclear nodules slenderly ellipsoid to ellipsoid, about 9-19 × 4$10 \mu \mathrm{m}$ in size (after protargol staining). Micronuclei about $2.9 \times 2.4 \mu \mathrm{m}$ in size (after protargol staining) (Fig. 2j). One contractile vacuole measuring about $13 \mu \mathrm{m}$ in diameter in diastole, positioned near left margin, contracting at intervals of $10 \mathrm{~s}$ (Fig. 2g, h). Cortical granules colourless, round, about $0.5 \mu \mathrm{m}$ in diameter, around dorsal ciliary organelles, visible in protargol preparations (Fig. 2c, j). Cytoplasm colourless, usually packed with numerous small lipid droplets. Locomotion mainly by slowly crawling on substrate and debris, sometimes jerking back and forth. When suspended, cells often swim continuously in circles.

Infraciliature during interphase as shown in Fig. 2 (b, e, f, i-l). Adoral zone of membranelles shaped as in other amphisiellid species, terminates at 11-20\% (average about 16\%) of body length. Adoral zone of membranelles separated by an inconspicuous gap, distal portion composed of five membranelles and separated from proximal portion, which is composed of nine to 14 (11 on average) membranelles. Cilia of distal membranelles $13 \mu \mathrm{m}$ long. Buccal cavity small and flat, endoral and paroral bending strongly and optically intersecting with each other at their lower middle regions (Fig. 2b, e, i, k). 
Cirral pattern and number of cirri of usual invariability. Most somatic cirri relatively fine with cilia about 12-16 $\mu \mathrm{m}$ long in life. Consistently three relatively stout frontal cirri in an almost transverse pseudo row immediately behind several distal adoral membranelles, cilia about $15 \mu \mathrm{m}$ long. Buccal cirrus absent. Amphisiellid median cirral row (ACR) short and consisting of four cirri; commences at about the level of the rightmost frontal cirrus (about $6 \%$ of body length), or slightly lower, terminates at about level of buccal vertex (about $21 \%$ of body length). Parabuccal cirrus (cirrus III/2) located at the level of the middle region of the paroral and endoral. Frontoventral row in region between parabuccal cirrus and ACR, consistently composed of two cirri; commences at about the level of the second cirrus in ACR (about $8 \%$ of body length) and terminates ahead of the third cirrus in ACR (about $10 \%$ of body length). Three, rarely two or four, slightly subterminal transverse cirri, cilia of which about $16 \mu \mathrm{m}$ long. Consistently one left and one right marginal row, each with 34-52 and 34-53 cirri, respectively. Right marginal cirral row begins dorsolaterally at anterior end of cell while left marginal cirral row begins at level of posterior end of adoral zone, both of them terminate caudally, but are not confluent (Fig. 2b, e, i, k, I).

Three dorsal kineties arranged in Gonostomum-pattern, with cilia about $3 \mu \mathrm{m}$ in length, composed of about 13, 15 and 15 dikinetids, respectively, and arrange in a gradient; that is, kinety 3 commences apically, kinety 2 starts slightly behind kinety 3 , while kinety 1 starts slightly behind kinety 2 . All of them terminate at the posterior body end (Fig. 2f, j).

\section{Morphogenesis during binary fission (Figs. 3a-h, 4a-c)}

Stomatogenesis. Cortical morphogenesis in Parasincirra sinica n. sp. mainly occurs in two zones: an anterior field for the proter and a posterior field for the opisthe.

In the opisthe, the first evidence of stomatogenesis during cell division is the appearance of groups of basal bodies on the cell surface, that is, the opisthe's oral primordium, which is located in the end of ACR, indicating that parental basal bodies are incorporated in the primordium (Fig. 3a). These groups subsequently merge by further proliferation of basal bodies forming a single anarchic field and then the new adoral membranelles organise posteriad (Figs. 3b, 5e). The anlage for the undulating membranes (anlage I) is formed to the right of the oral primordium (Figs. 3c, 5e). Later, the left frontal cirrus develops from the anterior end of the UM-anlage(Figs. 4a, 5n). During the later stages, the differentiation of membranelles is completed, forming the new oral structure for the opisthe. Subsequently, UM-anlage gives rise to the leftmost frontal cirrus, new endoral and paroral for the opisthe (Figs. 4a, b, 5n).

In the proter, several of the proximal membranelles dedifferentiate into sparsely distrusted bosal bodies, then the basal bodies differentiate into membranelles (Fig. 3c-e). The parental undulating membranes dedifferentiate into UM-anlage, then the basic development of the UM-anlage follows a similar pattern to that in the opisthe (Figs. 3b-e, g, 4a, 5d, e, m).

Development of the frontoventral-transverse cirri. The development of the somatic ciliature begins with the formation of the frontoventral-transverse cirral anlagen (FVT-anlagen). At the beginning, FVT-anlagen appear as a small group of basal bodies (Fig. 3a). Apparently, the parental frontoventral cirri are 
disaggregated and joined in the formation of the FVT-anlagen. Later, five FVT-anlagen are formed to the right of the UM-anlage in the proter as primary primordia (Figs. 3b, 5d). Then, the FVT-anlagen fragment in the middle to form two sets of anlagen, one set for the proter and the other for the opisthe (Figs. 3d, e, $5 h, i)$.

Subsequently, cirri segregate from anterior to posterior in the following manner: anlage I develops the frontal cirrus I/1 (leftmost frontal cirrus); anlage II produces the middle frontal cirrus; anlage III generates a parabuccal cirrus and the rightmost frontal cirrus; anlage IV contributes two cirri forming a short frontoventral cirral row; anlage $\mathrm{V}$ produces the posterior two cirri in ACR, and anlage $\mathrm{VI}$ forms the anterior two cirri in ACR; while anlagen IV to VI produce one transverse cirrus each (Figs. 4a, b, 5m, p). Finally, the new cirri move towards their final positions.

Development of marginal rows and dorsal kineties. Within every parental marginal row a few cirri near the anterior end, and a few others below the mid-body, differentiate to form two separate anlagen

The dorsal kineties develop by intrakinetal basal body proliferation, i.e. two anlagen develop in each parental row. Subsequently, the new marginal cirri/kineties develop and replace the old ones (Figs. 3d-h, $4 a-c, 5 g, h, j, m)$.

Division of nuclear apparatus. The nuclear apparatus divides in the usual way for hypotrichs hence no need to describe in detail (Figs. 3f, h, 4c, 5k).

\section{SSU rRNA gene sequence and phylogenetic analyses (Fig. 7)}

The sequence of the 18S rRNA gene of Parasincirra sinica n. sp. (GenBank accession number: MN472864) is $1731 \mathrm{bp}$ long and has a $\mathrm{G}+\mathrm{C}$ content of $45.70 \%$. Phylogenetic trees inferred from the SSU rDNA sequences using two different methods ( $\mathrm{ML}$ and $\mathrm{BI}$ ) show similar topologies. Therefore, only the ML topology is shown, with nodal support from both methods (Fig. 7).

Molecular phylogenetic analyses result in a clade containing four polytomies represented by Parasincirra sinica n. sp., two Uroleptoides species and Parabistichella variabilis with high support (83 \% ML, $1.00 \mathrm{BI}$, Fig. 7). They also confirm the polyphyly of other amphisiellids including species belonging to the type genus Amphisiella.

\section{Discussion}

\section{Comparison with similar genera}

Amphisiellidae were divided into three groups by Berger (2008) [29]. Group I comprises marine taxa (Amphisiella, Caudiamphisiella, Maregastrostyla and Spiroamphisiella). All of these possess a buccal cirrus and a very prominent ACR, commencing at about the level of the distal end of the adoral zone of membranelles, and terminating beyond the midbody. Hence the new genus, Parasincirra n. g., can be distinguished from others in group I. 
The group II genera (Lamtostyla and Uroleptoides) exhibit a continuous adoral zone of membranelles and possess a buccal cirrus whereas Parasincirran. g. has a bipartite adoral zone of membranelles and lacks a buccal cirrus. Parasincirra n. g. can therefore be easily distinguished by these morphological characteristics.

Group III comprises two genera, i.e. Lamtostylides and Paramphisiella. These possess a buccal cirrus and have only one cirrus (cirrus III/2) left of the ACR. In Parasincirra n. g., however, there is no buccal cirrus and one frontoventral cirri left of the ACR. So, the new genus also differs from species of this group.

Up to now, six genera, that is, Afroamphisiella, Cossothigma, Hemisincirra, Mucotrichidium, Terricirra and Tetrastyla, are incertae sedis in Amphisiellidae. With reference to the general infraciliature, Hemisincirra appears to be a close form to Parasincirra n. g., however, the type species of Hemisincirra has a buccal cirrus (vs. absent in Parasincirra n. g.). Afroamphisiella can be distinguished from Parasincirra n. g. since it possesses a buccal cirrus (vs. absent) and lacks transverse cirri (vs. present). Cossothigma can be separated from the new genus through its trachelostylid body shape and oral apparatus (vs. elliptical to elongate elliptical in shape and oral apparatus in Oxytricha-pattern), and the probable presence of caudal cirri (vs. absent in the new genus). Mucotrichidium differs from the new genus in having a continuous adoral zone of membranelles (vs. bipartite), and in possessing a buccal cirrus, postperistomial cirrus and caudal cirri (vs. absent in Parasincirra n. g.). Terricirra and Tetrastyla can also be separated from Parasincirra n. g.; Terricirra possesses a buccal cirrus (vs. absent in Parasincirra n. g.) while Tetrastyla has a continuous adoral zone of membranelles (vs. bipartite in Parasincirra n. g.).

\section{Comparison of Parasincirra sinica n. sp. with similar species}

Species assigned to Hemisincirra have an infraciliature which is very similar to that of our new species; namely, three frontal cirri, a short amphisiellid median cirral row, fewer transverse cirri and a lack of caudal cirri.

Considering its somatic ciliature, our new species resembles Hemisincirra interrupta and $H$. vermicularis most in that these species also have a bipartite adoral zone of membranelles and lack a buccal cirrus. Discrepancies between Parasincirra sinica n. sp. and H. interrupta, however, are that the latter possesses fewer dorsal kineties (one vs. three), and more macronuclear nodules (about 30 vs. two to six) as well as more cirri in amphisiellid median cirral row (six to eight vs. invariably four). Hemisincirra vermicularis differs from Parasincirra sinica n. sp. in having more macronuclear nodules (about ten vs. two to six) and contractile vacuoles (four vs. one), and fewer dorsal kineties (one vs. three) [29].

In terms of the somatic ciliature, Lamtostyla decorata, L. perisincirra, L. islandica, Uroleptoides magnigranulosus and $U$. longiseries closely resembles Parasincirra sinica $\mathrm{n}$. $\mathrm{sp}$. and thus should be compared.

Parasincirra sinica n. sp. differs from Lamtostyla decorata in: (i) smaller body size (90-140 × 20-40 $\mu \mathrm{m}$ vs. $100-220 \times 20-35 \mu \mathrm{m}$ ); (ii) buccal cirrus and pretransverse cirri absent (vs. present); (iii) fewer 
transverse cirri (two to four vs. five to nine); and (iv) adoral zone of membranelles bipartite (vs. continuous) [29].

Discrepancies between Parasincirra sinica n. sp. and Lamtostyla perisincirra are also observed in (i)

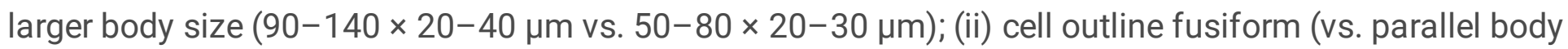
margins with both ends broadly rounded); (iii) buccal cirrus absent (vs. present); (iv) larger number of cirri in ACR (four vs. six to eight); (v) cortical granules present (vs. absent); and (vi) adoral zone of membranelles bipartite (vs. continuous) [29].

Parasincirra sinica n. sp. appears to be a close form to Lamtostyla islandica, but the former can be recognised by: (i) larger body size $(90-140 \times 20-40 \mu \mathrm{m}$ vs. $60-80 \times 20-25 \mu \mathrm{m})$ in vivo; (ii) cell outline fusiform (vs. parallel body margins with both ends broadly rounded); (iii) buccal cirrus absent (vs. present); (iv) adoral zone of membranelles interrupted (vs. continuous); (v) cortical granules present (vs. absent); and (vi) arrangement of endoral and paroral (at about same level vs. overlapping only by about half of their length) [29].

Uroleptoides magnigranulosus has a close relationship to Parasincirra sinica n. $\mathrm{sp}$. in the SSU rDNA tree of our present work. Parasincirra sinica n. sp., however, can be recognised by: (i) buccal cirrus absent (vs. present); (ii) lower number of cirri in ACR (four vs. 12-19) and transverse cirri (two to four vs. constantly five); and (iii) adoral zone of membranelles interrupted (vs. continuous) [29].

The dissimilarity between Parasincirra sinica n. sp. and Uroleptoides longiseries exists in buccal cirrus absent (vs. present in the latter), fewer cirri in ACR (four vs. 24-54 in the latter), and adoral zone of membranelles interrupted (vs. continuous in the latter) in the former [29].

\section{Morphogenetic comparison}

One of the most remarkable morphogenetic features in Parasincirra sinica $\mathrm{n}$. $\mathrm{sp}$. is that the rightmost frontoventral row is formed by two anlage, which is a specific character for amphisiellids and called the amphisiellid median cirral row. Hitherto, accounts of morphogenesis are available for only several taxa in Amphisiellidae with the main morphogenesis comprising a diversity of processes:

1. the parental adoral zone of membranelles is completely retained in some genera/species, e.g. Amphisiella, Lamtostyla, Lamtostylides, Paramphisiella and Hemisincirra inquieta, while it is partly renewed in other taxa, e.g. Parasincirra n. g.;

2. ventral cirri develop from five (e.g. Lamtostylides and Paramphisiella), six (e.g. Amphisiella, Parasincirra n. g., Spiroamphisiella, Hemisincirra inquieta, Terricirra, Mucotrichidium and most Lamtostyla species) or seven (e.g. Lamtostyla salina) FVT-anlagen;

3. FVT-anlage II generates the buccal cirrus (in Amphisiella, Spiroamphisiella, Lamtostyla, Lamtostylides, Paramphisiella, Afroamphisiella, Hemisincirra inquieta, Terricirra and Mucotrichidium) or not (in Parasincirra n. g.); 
4. the amphisiellid median cirral row is formed by two (in Amphisiella, Hemisincirra inquieta, Parasincirra n. g., Lamtostyla, Lamtostylides, Mucotrichidium and Paramphisiella) or three (in Terricirra and Spiroamphisiella) anlagen;

5. caudal cirri are formed in some taxa, i.e. Spiroamphisiella, Paramphisiella and Mucotrichidium, while not formed in other genera, i.e. Amphisiella, Parasincirra n. g., Lamtostyla, Lamtostylides, Afroamphisiella, Hemisincirra inquieta and Terricirra;

6. no transverse cirri are formed in Afroamphisiella and Paramphisiella while transverse cirri are formed in Amphisiella, Parasincirra n. g., Lamtostyla, Lamtostylides, Terricirra, Mucotrichidium, Hemisincirra inquieta and Spiroamphisiella [29, 31-33].

\section{Phylogenetic analyses}

Molecular phylogenetic analyses cannot resolve the relationship of the four polytomies represented by Parasincirra, Uroleptoides and Parabistichella genera (Fig. 6, 7). Whether or not the assignments of the latter two genera to the family Amphisiellidae need further clarification [26, 29, 30, 32, 34-38], the new genus Parasincirra has the critical character of the family Amphisiellidae of an ACR that originates from two separate anlagen, and apparently it should be assigned in this family $[28,29]$. Furthermore, the genera within this clade share the same three enlarged frontal cirri and one marginal cirral row on each side pattern. The main difference between Parabistichella and Parasincirra is the number and origin of the frontoventral rows; that is, the most remarkable morphogenetic features in Parasincirra is the long frontoventral row (= amphisiellid cirral row) formed by two anlage while it is formed by just a single anlage in Parabistichella. The main difference between the species of the genera Uroleptoides and Parasincirra, meanwhile, is whether or not the buccal cirrus appears [29,34-36]. The reason why these obvious differences in morphological characters are not reflected in the phylogeny might simply be that there is currently insufficient data to figure out how those lineages are related [39]. By contrast, the phylogenetic relationship between $P$. sinica and the most morphologically similar genus, Lamtostyla, shows a high intra-node scattering, which might indicate that the critical character of the family Amphisiellidae (the ACR originating from two separate anlagen) is a plesiomorphic trait within the amphisiellid hypotrichs evolving independently under different conditions.

Moreover, other amphisiellid species, even for the type genus Amphisiella, are also not resolved well in our phylogenetic analyses, as has also been the case in previous studies (Fig. 7) [32, 34, 37]. Given the species being sampled and the deficient data on the morphogenesis and SSU rDNA sequences, there is insufficient evidence to unravel a robust phylogeny for this complex group [30,32,34-37, 40]. Future studies therefore need to gather more data on other gene markers and morphogenetic studies from a wider range of taxa in order to begin to develop a more accurate classification and evolution of Parasincirra and its relationship with other amphisiellid species.

\section{Materials And Methods}

\section{Sample collection, isolation, and culturing}


Sludge soil samples were collected from the upper $10 \mathrm{~cm}$ layer within a flood drain in Lanzhou $\left(36^{\circ} 3^{\prime} \mathrm{N}\right.$; $103^{\circ} 49^{\prime} \mathrm{E}$ ), China on 30 April 2017 (Fig. 1). Samples were dried at room temperature (about $24^{\circ} \mathrm{C}$ ) immediately after collection in order to preserve them. Months later, ciliates were induced to excyst from the soil samples by employing the non-flooded Petri dish method described by Foissner (2014) [41]. They were then isolated in the laboratory using micropipettes and non-clonal cultures were established at room temperature in Petri dishes with mineral water (Nongfu Spring), with grains of rice being added in order to stimulate the growth of bacteria to act as a food source for the ciliates. We identified only one species, and relied on in vivo morphologic characteristics to assure the accuracy of that identification for all downstream analyses, even though we were unable to establish clonal cultures. Moreover, no other stichotrichid morphotypes were present in the protargol preparation.

\section{Morphology and morphogenetic studies}

Live observations were carried out using bright field and differential interference contrast microscopy (Olympus BX51) and photographed using a digital camera. Protargol preparation was used to reveal the ciliature and the nuclear apparatus [42]. The protargol reagent was synthesised following the protocol of Pan et al. (2013) [43]. Counts and measurements of stained specimens were performed at a magnification of 1,000x. Drawings of protargol-prepared cells were made with the assistance of a drawing device (camera lucida). To illustrate the changes that occurred during morphogenesis, parental structures are depicted by contour whereas new structures are shaded black $[44,45]$. Terminology is according to Berger (2008) [29] and the systematic classification follows Lynn (2008) [28].

\section{DNA extraction, PCR amplification, and gene sequencing}

Single cells of Parasincirra sinica were isolated from samples, washed several times with distilled water using a micropipette in order to remove potential contamination, and then transferred to three different $1.5 \mathrm{~mL}$ microfuge tubes with a minimum volume of water. DNA extraction was performed with the DNeasy Blood \& Tissue Kit (Qiagen) following the manufacturer's instructions with minor modifications [46]. PCR amplification and sequencing of the SSU rDNA were performed according to Sheng et al. (2018) [47] using high fidelity Takara Ex Taq DNA polymerase (Takara Ex Taq; Takara Biomedicals) to minimise the possibility of amplification errors. The PCR products were purified using Geneclean (BIO 101 Inc., La Jolla, CA) and sequenced bidirectionally on the ABI 3700 sequencer (GENEWIZ Biotechnology Co., Ltd., Beijing, China).

\section{Phylogenetic analyses}

The SSU rDNA sequence of the new species, together with 54 representative taxa downloaded from the GenBank database, were used in the present phylogenetic analyses. Several oligotrich species (Novistrombidium sinicum, Strombidium cuneiforme and S. apolatum) were selected as putative outgroups. All sequences were aligned using the GUIDANCE web server (http://guidance.tau.ac.il/) [48]. The resulting alignment was manually edited using the program BioEdit 7.0 [49]. Both Maximum likelihood (ML) and Bayesian inference (BI) analyses were performed on the final alignment under the 
best-fit nucleotide substitution model of $\mathrm{GTR}+\Gamma$ that was selected by jModelTest ver. 2.1.7 [50]. The ML analysis was performed using RAXML-HPC2 on XSEDE v8.2.12 on the online server CIPRES Science Gateway [51], with 1,000 rapid bootstrap replicates and a subsequent thorough $M L$ search. Bayesian inference was computed with MrBayes on XSEDE 3.2.6 [52], running four Markov chains sampling every 100 generations for a million generations and discarding the first $25 \%$ of trees as burn-in. The majority rule consensus tree was produced from the remaining samples with each node labelled with its posterior probability. SeaView v.4 [53] and MEGA v5 [54] were used to visualise the tree topologies.

\section{Declarations}

\section{Acknowledgements}

Many thanks are given to Dr Jie Huang, Chinese Academy of Sciences, for her help with phylogenetic analyses.

\section{Funding}

This work was supported by the Natural Science Foundation of China (Project numbers: 31872190 ) and Researchers Supporting Project number (RSP-2019), King Saud University, Riyadh, Saudi Arabia.

\section{Authors' contributions}

MJ carried out the live observation, protargol impregnation. MJ, ZY, ZT was responsible for DNA amplification and sequencing, and the molecular phylogenetic analyses. Manuscript drafting: MJ, SC, ZY, ZT; Manuscript review and editing: SC, ZY, SW. (all authors helped revise the manuscript. All authors read and approved the final manuscript).

\section{Availability of data and materials}

Sequence data is available in GenBank (Accession Numbers: MN472864). Several permanent slides containing the protargol-impregnated holotype specimen of Parasincirra sinica n. sp., with registration number of MJY2017043001 are deposited in the Laboratory of Protozoological Biodiversity and Evolution in Wetland, Shanxi Normal University.

\section{Ethics approval and consent to participate}

Not applicable.

\section{Consent for publication}

Not applicable.

\section{Competing interests}

The authors declare that they have no competing interests. 


\section{References}

1. Chen L, Wu W, El-Serehy HA, Hu X, Clamp JC. Morphology, morphogenesis, and phylogeny of an Anteholosticha intermedia (Ciliophora, Urostylida) population from the United States. Eur J Protistol. 2018;65:1-15.

2. Chen X, Jiang Y, Gao F, Zheng W, Krock TJ, Stover NA, et al. Genome analyses of the new model protist Euplotes vannus focusing on genome rearrangement and resistance to environmental stressors. Mol Ecol Res. 2019;doi:10.1111/1755-0998.13023.

3. Li X, Huang J, Filker S, Stoeck T, Bi Y, Yu Y, et al. Spatio-temporal patterns of zooplankton in a mainstem dam affected tributary: a case study in the Xiangxi River of the Three Gorges Reservoir, China. Sci China Life Sci. 2019;62:1058-1069.

4. Song W, Shao C. Ontogenetic Patterns of Hypotrichs Ciliates. Science Press (in Chinese). 2017.

5. Song W, Warren A, Hu X. Free-living Ciliates in the Bohai and Yellow Seas, China. Science Press. 2009.

6. Wang $Y$, Chen X, Sheng Y, Liu Y, Gao S. $N^{6}$-adenine DNA methylation is associated with the linker DNA of H2A.Z-containing well-positioned nucleosomes in Pol II-transcribed genes in Tetrahymena. Nuc Acid Res. 2017;45:11594-11606.

7. Xu J, Li X, Song W, Wang W, Gao S. Cyclin cyc2p is required for micronuclear bouquet formation in Tetrahymena thermophila. Sci China Life Sci. 2019;62: 62-74.

8. Zhang T, Fan X, Gao F, Al-Farraj SA, El-Serehy HA, Song W. Further analyses on the phylogeny of the subclass Scuticociliatia (Protozoa, Ciliophora) based on both nuclear and mitochondrial data. Mol Phylog Evol. 2019;doi:10.1016/j.ympev.2019.106565.

9. Berger H. Monograph of the Gonostomatidae and Kahliellidae (Ciliophora, Hypotricha). Monogr Biol. 2011;91:1-741.

10. Hu X, Lin X, Song W. Ciliates atlas: species found in the South China Sea. Science Press, Beijing. 2019.

11. Jung JH, Cho J, Jang YH, Gil DY. Morphology and molecular phylogeny of Holostichides terrae nov. spec. (Ciliophora: Spirotrichea) with discussion on the possible non-monophyly of Holostichides. Eur J Protistol. 2018;62:69-78.

12. Kaur H, Shashi, Negi RK, Kamra K. Morphological and molecular characterization of Neogastrostyla aqua nov. gen., nov. spec. (Ciliophora, Hypotrichia) from River Yamuna, Delhi; comparison with Gastrostyla-like genera. Eur J Protistol. 2019;68:68-79.

13. Kumar S, Bharti D, Kabir AS, Hong JS, Shin MK. Rubrioxytricha guamensis nov. spec. (Ciliophora, Spirotricha), a novel hypotrich ciliate from Guam (United States), Micronesia. J Eukaryot Microbiol. 2018;65:392-399.

14. Méndez-Sánchez D, Mayén-Estrada R, Luo X, Hu X. A new subspecies of Oxytricha granulifera (Hypotrichia: Oxytrichidae) from Mexico, with notes on its morphogenesis and phylogenetic position. J Eukaryot Microbiol. 2018;65:357-371. 
15. Lu X, Huang J, Shao C, Berger H. Morphology, cell-division, and phylogeny of Schmidingerothrix elongata spec. nov. (Ciliophora, Hypotricha), and brief guide to hypotrichs with Gonostomum-like oral apparatus. Eur J Protistol. 2018;62:24-42.

16. Luo X, Yan Y, Shao C, Al-Farraj SA, Bourland WA, Song W. Morphological, ontogenetic and molecular data support strongylidiids as being closely related to Dorsomarginalia (Protozoa, Ciliophora) and reactivation of the family Strongylidiidae Fauré-Fremiet, 1961. Zool J Linn Soc. 2018;184:237-254.

17. Luo X, Huang J, Li L, Song W, Bourland WA. Phylogenetic of the ciliate family Psilotrichidae (Protista, Ciliophora), a curious and poorly-known taxon, with notes on two algae-bearing psilotrichids from Guam, USA. BMC Evol Biol. 2019;19:125. doi.org/10.1186/ s12862-019-1450-z

18. Lyu Z, Li J, Qi S, Yu Y, Shao C. Morphology and morphogenesis of a new soil urostylid ciliate, Australothrix xianiensis nov. spec. (Ciliophora, Hypotrichia). Eur J Protistol. 2018a;64:72-81.

19. Lyu Z, Li J, Zhu E, Shao C. Morphology and morphogenesis of a new soil urostylid ciliate, with the establishment of a new genus Caudiurostyla gen. nov. (Ciliophora, Hypotrichia). Eur J Protistol. 2018b;66, 166-176.

20. Lyu Z, Wang J, Huang J, Warren A, Shao C. Multigene based phylogeny of Urostylida (Ciliophora, Hypotrichia), with establishment of a novel family. Zool Scr. 2018c;47:243-254.

21. Shao C, Hu C, Fan Y, Warren A, Lin X. Morphology, morphogenesis and molecular phylogeny of a freshwater ciliate, Monomicrocaryon euglenivorum euglenivorum (Ciliophora, Oxytrichidae). Eur J Protistol. 2019;68:25-36.

22. Song Y, Liu Y, Pan B, Luo X, Song W, Warren A. Morphological studies on four brackish water ciliates of the class Spirotrichea (Protista, Ciliophora). J Ocean U China. 2019;18:663-674.

23. Wang $Y$, Wang $C$, Jiang $Y$, Katz L, Gao F, Yan Y. Further analyses of variation of ribosome DNA copy number and polymorphism in ciliates provide insights relevant to studies of both molecular ecology and phylogeny. Sci China Life Sci. 2019b;62:203-214.

24. Zhang T, Qi H, Zhang T, Sheng Y, Warren A, Shao C. Morphology, morphogenesis and molecular phylogeny of a new brackish water subspecies, Neourostylopsis flava paraflava nov. subsp.

(Ciliophora, Hypotrichia, Urostylidae), with redefinition of the genus Neourostylopsis. Eur J Protistol. 2018;66:48-62.

25. Luo X, Huang J, Li L, Song W, Bourland WA. Phylogeny of the ciliate family Psilotrichidae (Protista, Ciliophora), a curious and poorly-known taxon, with notes on two algae-bearing psilotrichids from Guam, USA. BMC Evolutionary Biology. 2019;19(1):125.

26. Gao F, Warren A, Zhang Q, Gong J, Miao M, Sun P, et al. The all-data-based evolutionary hypothesis of ciliated protists with a revised classification of the phylum Ciliophora (Eukaryota, Alveolata). Sci Rep. 2016;6:24874.

27. Fernandes NM, Schrago CG. A multigene timescale and diversification dynamics of Ciliophora evolution. Mol Phylogenet Evol. 2019;doi.org/10.1016/j.ympev.2019.106521.

28. Lynn D. The ciliated protozoa: Characterization, classification and guide to the literature, 3rd ed. Springer Press, Dordrecht. 2008. 
29. Berger H. Monograph of the Amphisiellidae and Trachelostylidae (Ciliophora, Hypotricha). Monogr Biol. 2008;88:1-737.

30. Wang J, Li J, Qi S, Warren A, Shao C. Morphogenesis and molecular phylogeny of a soil ciliate Uroleptoides longiseries (Foissner, Agatha and Berger, 2002) Berger, 2008 (Ciliophora, Hypotrichia). J Eukaryot Microbiol. 2019a;66:334-342.

31. Chen X, Shao C, Lin X, Clamp JC, Song W. Morphology and molecular phylogeny of two new brackish-water species of Amphisiella (Ciliophora, Hypotrichia), with notes on morphogenesis. Eur J Protistol. 2013;49:453-466.

32. Dong J, Lu X, Shao C, Huang J, Al-Rasheid KAS. Morphology, morphogenesis and molecular phylogeny of a novel saline soil ciliate, Lamtostyla salina n. sp. (Ciliophora, Hypotricha). Eur J Protistol. 2016;56:219-231.

33. Li L, Zhao X, Ji D, Hu X, Al-Rasheid KAS, Al-Farraj SA, Song W. Description of two marine amphisiellid ciliates, Amphisiella milnei (Kahl, 1932) Horváth, 1950 and A. sinica sp. nov. (Ciliophora: Hypotrichia), with notes on their ontogenesis and SSU rDNA-based phylogeny. Eur J Protistol. 2016;54:59-73.

34. Fan Y, Hu X, Gao F, Al-Farraj SA, Al-Rasheid KAS. Morphology, ontogenetic features and SSU rRNA gene-based phylogeny of a soil ciliate, Bistichella cystiformans spec. nov. (Protista, Ciliophora, Stichotrichia). Int J Syst Evol Microbiol. 2014;64:4049-4060.

35. He Y, Xu K. Morphology and small subunit rDNA phylogeny of a new soil ciliate, Bistichella variabilis n. sp. (Ciliophora, Stichotrichia). J Eukaryot Microbiol. 2011;58:332-338.

36. Jiang J, Huang J, Li L, Shao C, Al-Rasheid KAS, Al-Farraj SA. et al. Morphology, ontogeny, and molecular phylogeny of two novel bakuellid-like hypotrichs (Ciliophora: Hypotrichia), with establishment of two new genera. Eur J Protistol. 2013;49:78-92.

37. Luo X, Yi Z, Gao F, Pan Y, Al-Farraj SA, Warren A. Taxonomy and molecular phylogeny of two new brackish hypotrichous ciliates, with the establishment of a new genus (Protozoa, Ciliophora). Zool J Linn Soc. 2016;179:475-491.

38. Yi Z, Song W. Evolution of the order Urostylida (Protozoa, Ciliophora): new hypotheses based on multi-gene information and identification of localized incongruence. Plos ONE. 2011.6(3):e17471

39. Wiens JJ. Missing data, incomplete taxa, and phylogenetic accuracy. Systematic Biol. 2003;52: 528538.

40. Huang J, Luo X, Bourland WA, Gao F, Gao S. Multigene-based phylogeny of the ciliate families Amphisiellidae and Trachelostylidae (Protozoa: Ciliophora: Hypotrichia). Mol Phylogenet Evol. 2016;101:101-110.

41. Foissner W. An update of 'basic light and scanning electron microscopic methods for taxonomic studies of ciliated protozoa'. Int J Syst Evol Microbiol. 2014;64:271-292.

42. Wilbert N. Eine verbesserte Technik der Protargolimprägnation für Ciliaten. Mikrokosmos 1975;64: 171-179. 
43. Pan X, Bourland W, Song W. Protargol synthesis: an in-house protocol. J Eukaryot Microbiol. 2013;60:609-614.

44. Bai Y, Li S, Li Y, Miao M, Hu X. Morphogenesis and molecular characterization of a little known soil ciliate, Oxytricha nauplia Berger et Foissner, 1987 (Ciliophora, Sporadotrichida). Acta Protozool. 2018;57(2):79-94.

45. Ning Y, Yang Y, Zhang T, Chen L, Al-Rasheid KAS, Yi Z. Integrative studies on the morphology, morphogenesis and molecular phylogeny of a soil ciliate, Parakahliella macrostoma (Foissner, 1982) Berger et al., 1985 (Ciliophora, Hypotrichia). Acta Protozool. 2018;57:107-122.

46. Gao F, Gao S, Wang P, Katz LA, Song W. Phylogenetic analyses of cyclidiids (Protista, Ciliophora, Scuticociliatia) based on multiple genes suggest their close relationship with thigmotrichids. Mol Phylogenet Evol. 2014;75:219-226.

47. Sheng Y, He M, Zhao F, Shao C, Miao M. Phylogenetic relationship analyses of complicated class Spirotrichea based on transcriptomes from three diverse microbial eukaryotes: Uroleptopsis citrina, Euplotes vannus and Protocruzia tuzeti. Mol Phylogenet Evol. 2018;129:338-345.

48. Penn O, Privman E, Ashkenazy H, Landan G, Graur D, Pupko T. GUIDANCE: a web server for assessing alignment confidence scores. Nucleic Acids Res. 2010;38:W23-W28.

49. Hall T. BioEdit: a user-friendly biological sequence alignment editor and analysis program for Windows 95/98/NT. Nucleic. Acids. Symp. Ser. 1999;41:95-98.

50. Darriba D, Taboada GL, Doallo R, Posada D. JModelTest 2: more models, new heuristics and parallel computing. Nat Methods. 2012;9:772.

51. Miller M, Pfeiffer W, Schwartz T. Creating the CIPRES science gateway for inference of large phylogenetic trees. In: Proceedings of the Gateway Computing Environments Workshop (GCE), New Orleans, LA. 2010.

52. Ronquist F, Teslenko M, van der Mark P, Ayres DL, Darling A, Höhna S. et al. MrBayes 3.2: efficient Bayesian phylogenetic inference and model choice across a large model space. Syst Biol. 2012;61:539-542.

53. Gouy M, Guindon S, Gascuel O. SeaView version 4: a multiplatform graphical user interface for sequence alignment and phylogenetic tree building. Mol Biol Evol. 2010;27:221-224.

54. Tamura K, Peterson D, Peterson N, Stecher G, Nei M, Kumar S. MEGA5: molecular evolutionary genetics analysis using maximum likelihood, evolutionary distance, and maximum parsimony methods. Mol Biol Evol. 2011;28:2731-2739.

55. Park KM, Chae N, Jung JH, Min GS, Kim S, Berger H. Redescription of Keronopsis helluo Penard, 1922 from Antarctica and Paraholosticha pannonica Gellért and Tamás, 1959 from Alaska(Ciliophora, Hypotricha). Eur J Protistol. 2017;60:102-118.

\section{Tables}

Table 1 
Morphometric characteristics of Parasincirra sinica n. sp.

\begin{tabular}{|c|c|c|c|c|c|c|c|c|}
\hline Character $^{a}$ & HT & Min & Max & Mean & M & SD & $\mathrm{CV}$ & $\mathrm{n}$ \\
\hline Body, length & 106 & 81 & 152 & 119.7 & 115 & 18.3 & 15.3 & 25 \\
\hline Body, width & 30 & 18 & 47 & 30.3 & 31 & 6.3 & 21.0 & 25 \\
\hline AZM, length & 19 & 13 & 24 & 19.1 & 19 & 2.5 & 13.0 & 25 \\
\hline AZM, length:body length ratio & 0.18 & 0.11 & 0.20 & 0.16 & 0.16 & 0.02 & 13.07 & 25 \\
\hline AZM, number & 16 & 14 & 19 & 15.6 & 15 & 1.3 & 8.1 & 25 \\
\hline Frontal adoral membranelles, number & 5 & 5 & 5 & 5.0 & 5 & 0 & 0 & 25 \\
\hline Ventral adoral membranelles, number & 11 & 9 & 14 & 10.7 & 10 & 1.2 & 11.4 & 25 \\
\hline PBC, number & 1 & 1 & 1 & 1.0 & 1 & 0 & 0 & 25 \\
\hline FVR, number & 2 & 2 & 2 & 2.0 & 2 & 0 & 0 & 25 \\
\hline $\mathrm{ACR}$, cirri number & 4 & 4 & 4 & 4.0 & 4 & 0 & 0 & 25 \\
\hline Frontal cirri, number & 3 & 3 & 3 & 3.0 & 3 & 0 & 0 & 25 \\
\hline Left marginal cirri, number & 44 & 34 & 52 & 41.3 & 41 & 5.3 & 12.9 & 25 \\
\hline Right marginal cirri, number & 40 & 34 & 53 & 41.2 & 39 & 5.2 & 12.6 & 25 \\
\hline Transverse cirri, number & 3 & 2 & 4 & 3.1 & 3 & 0.5 & 16.0 & 25 \\
\hline Dorsal kineties, number & 3 & 3 & 3 & 3.0 & 3 & 0 & 0 & 25 \\
\hline Dikinetids in DK1, number & 10 & 10 & 17 & 12.5 & 12 & 2.3 & 18.7 & 15 \\
\hline Dikinetids in DK2, number & 15 & 13 & 18 & 14.9 & 15 & 1.5 & 10.3 & 15 \\
\hline Dikinetids in DK3, number & 17 & 11 & 18 & 14.5 & 14 & 2.2 & 15.0 & 15 \\
\hline Macronuclear nodules, number & 4 & 2 & 6 & 4.1 & 4 & 0.7 & 16.2 & 25 \\
\hline Macronuclear nodule, average length & 10 & 9 & 19 & 13.8 & 14 & 2.8 & 20.4 & 25 \\
\hline Macronuclear nodule, average width & 5 & 4 & 10 & 6.0 & 6 & 1.2 & 20.4 & 25 \\
\hline Micronuclei, number & 2 & 1 & 3 & 2.0 & 2 & 0.7 & 37.5 & 25 \\
\hline Micronuclear nodule, average length & 3 & 2 & 4 & 2.9 & 3 & 0.4 & 14.5 & 25 \\
\hline Micronuclear nodule, average width & 2 & 2 & 4 & 2.4 & 2 & 0.4 & 18.0 & 25 \\
\hline
\end{tabular}

aAll data are based on protargol-stained specimens. Measurements in um. Abbreviations: ACR, Amphisiellid median cirral row; AZM, Adoral zone of membranelles; CV, coefficient of variation in \%; DK, Dorsal kineties; FVR, Frontoventral cirral row; HT, holotype specimen; M, median; Max, maximum; Mean, arithmetic mean; Min, minimum; n, sample size; PBC, parabuccal cirri; SD, standard deviation.

\section{Figures}




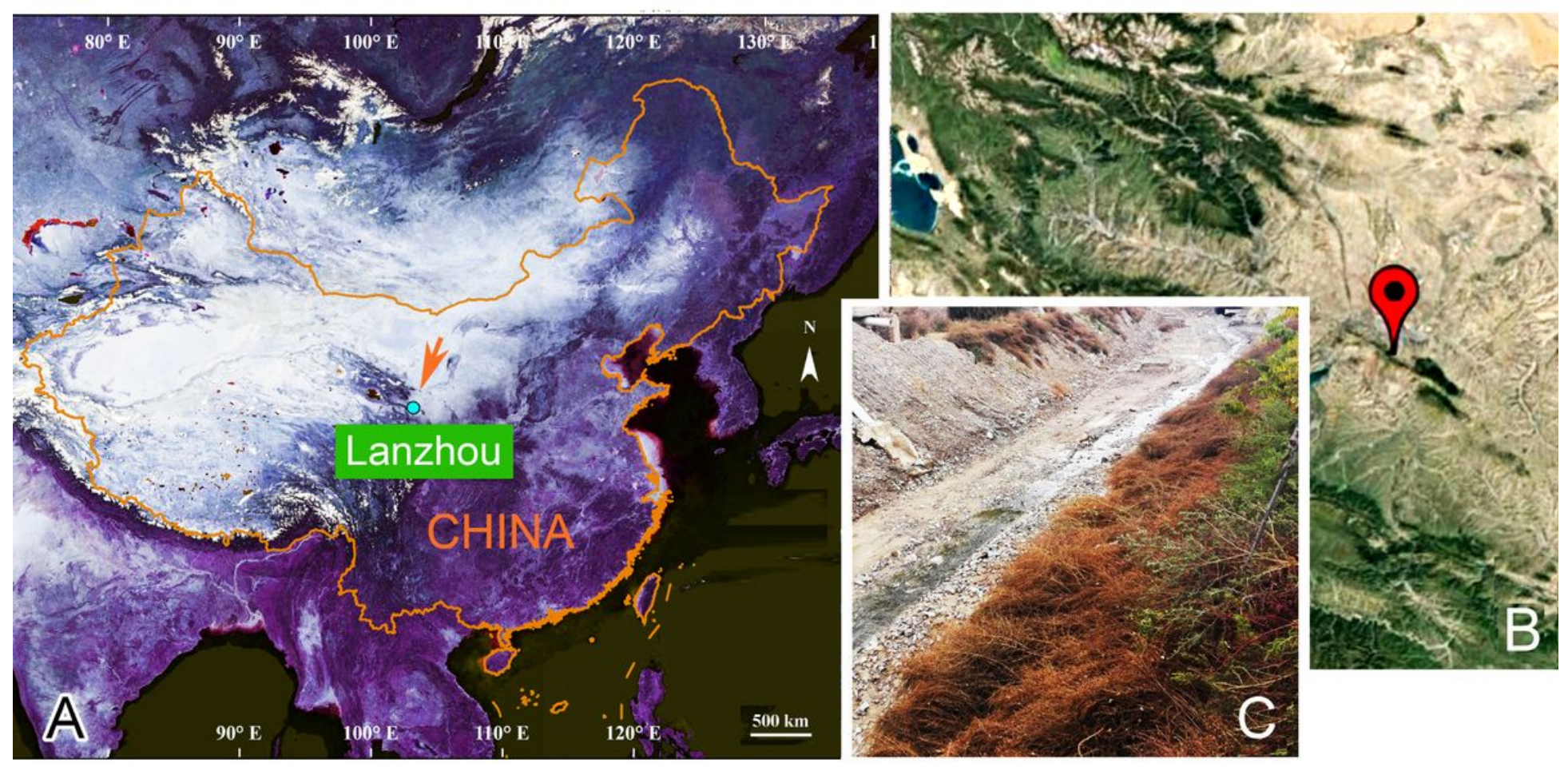

Figure 1

a-c. Locations of the sample sites. (a, b) Portion of Google map, showing the location of Lanzhou, China $\left(36^{\circ} 03^{\prime} \mathrm{N} ; 103^{\circ} 49^{\prime} \mathrm{E}\right)$. (c) Showing the area surrounding the flood drain from where the sample containing Parasincirra sinica n. sp. was collected. Note: The designations employed and the presentation of the material on this map do not imply the expression of any opinion whatsoever on the part of Research Square concerning the legal status of any country, territory, city or area or of its authorities, or concerning the delimitation of its frontiers or boundaries. This map has been provided by the authors. 


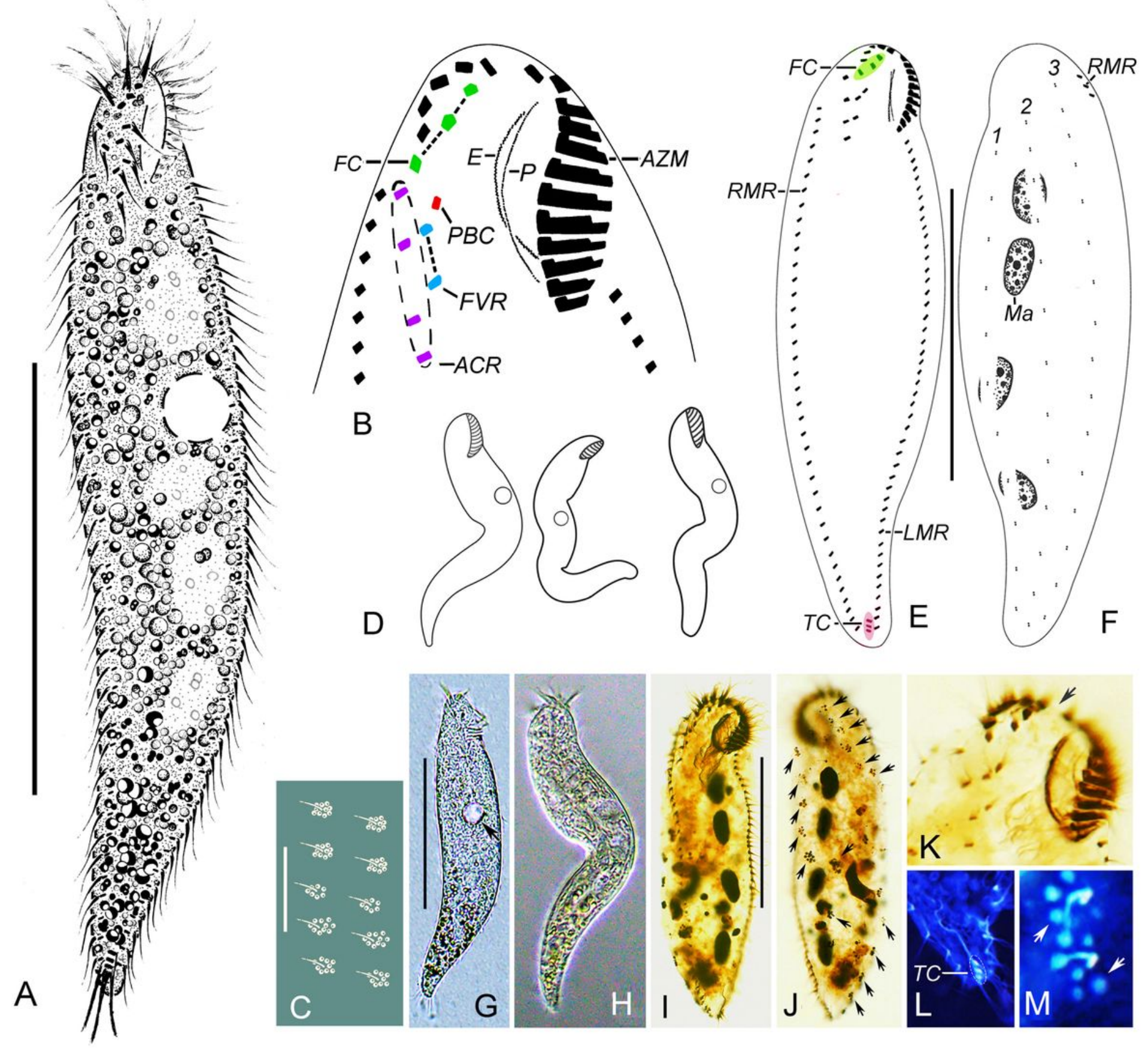

Figure 2

a-I. Morphology of Parasincirra sinica n. sp. from life $(a, c, d, g, h)$ and after protargol staining (b, e, f, iI). (a) Ventral view of a representative specimen. (b) Ventral view, to show ciliature of frontoventral area. (c) Arrangement of cortical granules on dorsal side. (d) Ventral views, to show the various body shapes. $(\mathrm{e}, \mathrm{f})$ Ventral (e) and dorsal (f) view of a typical individual, to show the ciliature and nuclear apparatus. (g, h) Ventral views of representative individuals, arrow indicates contractile vacuole. (i) Ventral view of the holotype specimen to show ventral ciliature. (j) Dorsal view to show cortical granules (arrows). (k) Ventral view of anterior portion, to show the cirri in frontoventral area and a short gap in adoral zone of membranelles. (I) Ventral view, to show transverse cirri. ACR, amphisiellid cirral row; AZM, adoral zone of membranelles; E, endoral; FC, frontal cirri; FVR, frontoventral cirral row; LMR, left marginal row; Ma, 
macronuclear nodules; Mi, micronuclei; P, paroral; PBC, parabuccal cirri; RMR, right marginal row; TC, transverse cirri; $1-3$, dorsal kineties $1-3$. Scale bars: $A, E, F, I=60 \mu \mathrm{m}, C=15 \mu \mathrm{m}$.
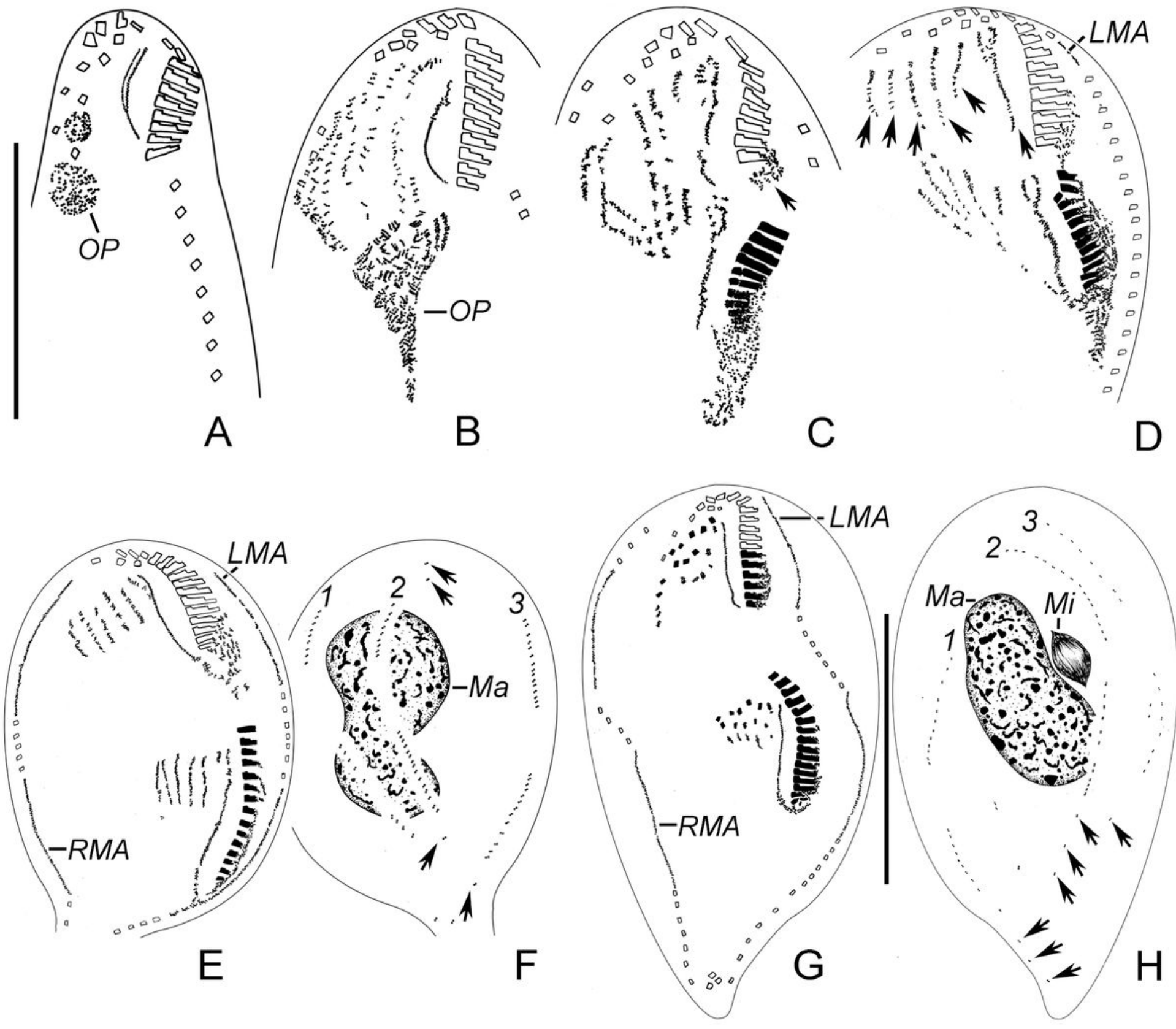

Figure 3

$\mathrm{a}-\mathrm{h}$. Early and middle stages of morphogenesis in Parasincirra sinica n. sp. after protargol staining. (a, b) Ventral views of early dividers, showing oral primordium of opisthe and frontoventral-transverse cirral anlagen. Note parental undulating membranes start to dedifferentiate (b). (c, d) Ventral views of later dividers, to show the development of oral primordium, frontoventral-transverse cirral anlagen and undulating membranes anlagen (arrows). Note the dedifferentiation of membranelles at the proximal end of the old adoral zone of membranelles (arrow in c), and the intrakinetally formed anlagen for the marginal rows (d). (e-h) Ventral $(e, g)$ and dorsal $(f, h)$ views of middle dividers, to show stretched marginal anlagen and dorsal kineties anlagen, the posterior membranelles of the parental adoral zone of 
membranelles renewed $(\mathrm{g})$ and the macronuclear nodules fusing into a single mass. Note the old dorsal dikinetids are not absorbed (arrows). OP, oral primordium; LMA, left marginal anlagen; LMR, left marginal row; Ma, macronuclear nodules; Mi, micronuclei; RMA, right marginal anlagen; RMR, right marginal row; 1-3, dorsal kineties anlagen $1-3$. Scale bars: $A, G, H=60 \mu \mathrm{m}$.
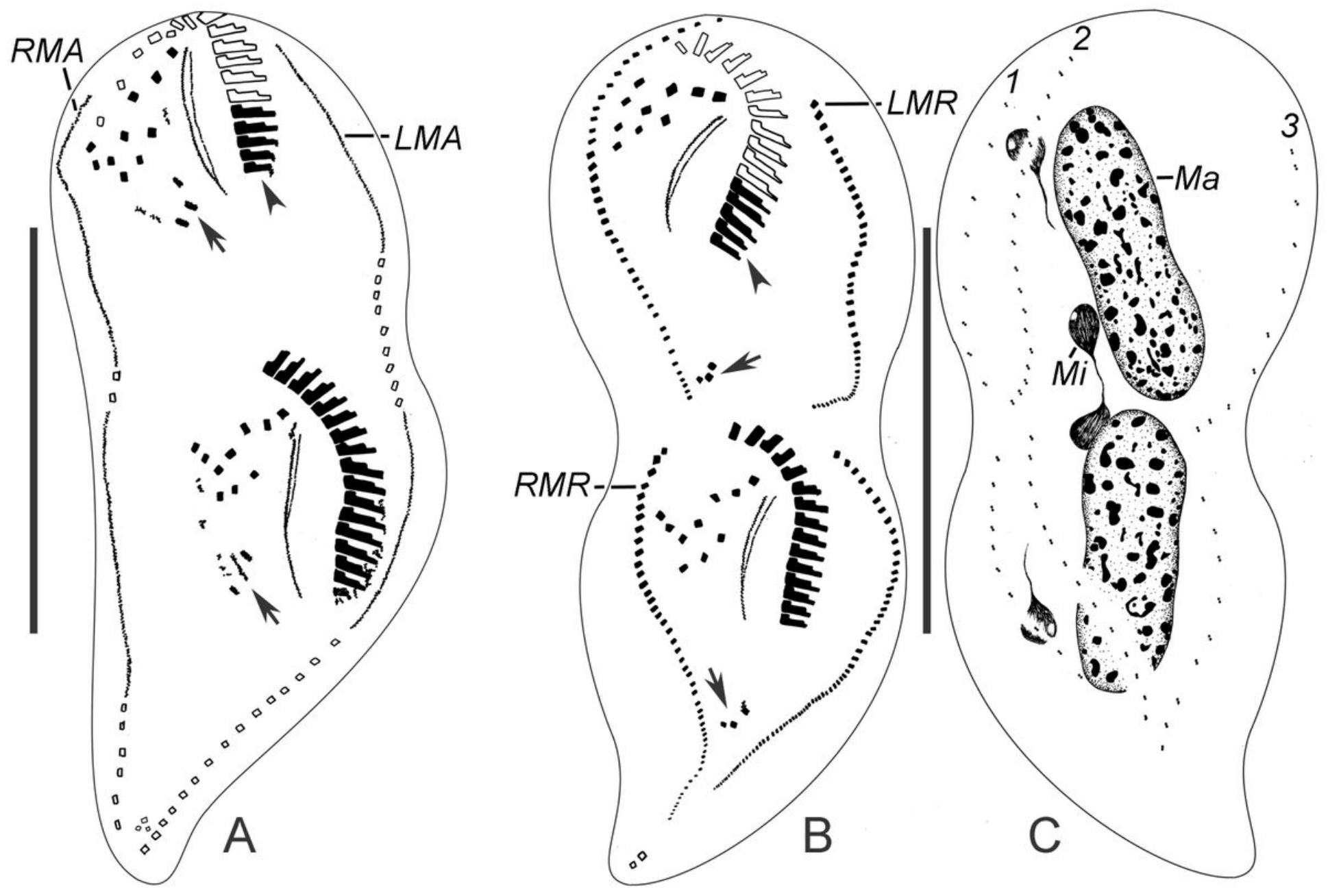

\section{Figure 4}

a-c. Late stages of morphogenesis in Parasincirra sinica n. sp. after protargol staining. Ventral $(a, b)$ and dorsal (c) views, to show the frontoventral-transverse cirral anlagen differentiating into cirri, transverse cirri migrating into their final position (arrows), the old adoral zone of membranelles have been rebuilt (arrowheads). LMA, left marginal anlagen; LMR, left marginal row; RMA, right marginal anlagen; RMR, right marginal row; Ma, macronuclear nodules; Mi, micronuclei; $1-3$, dorsal kineties anlagen 1-3. Scale bars $=60 \mu \mathrm{m}$. 


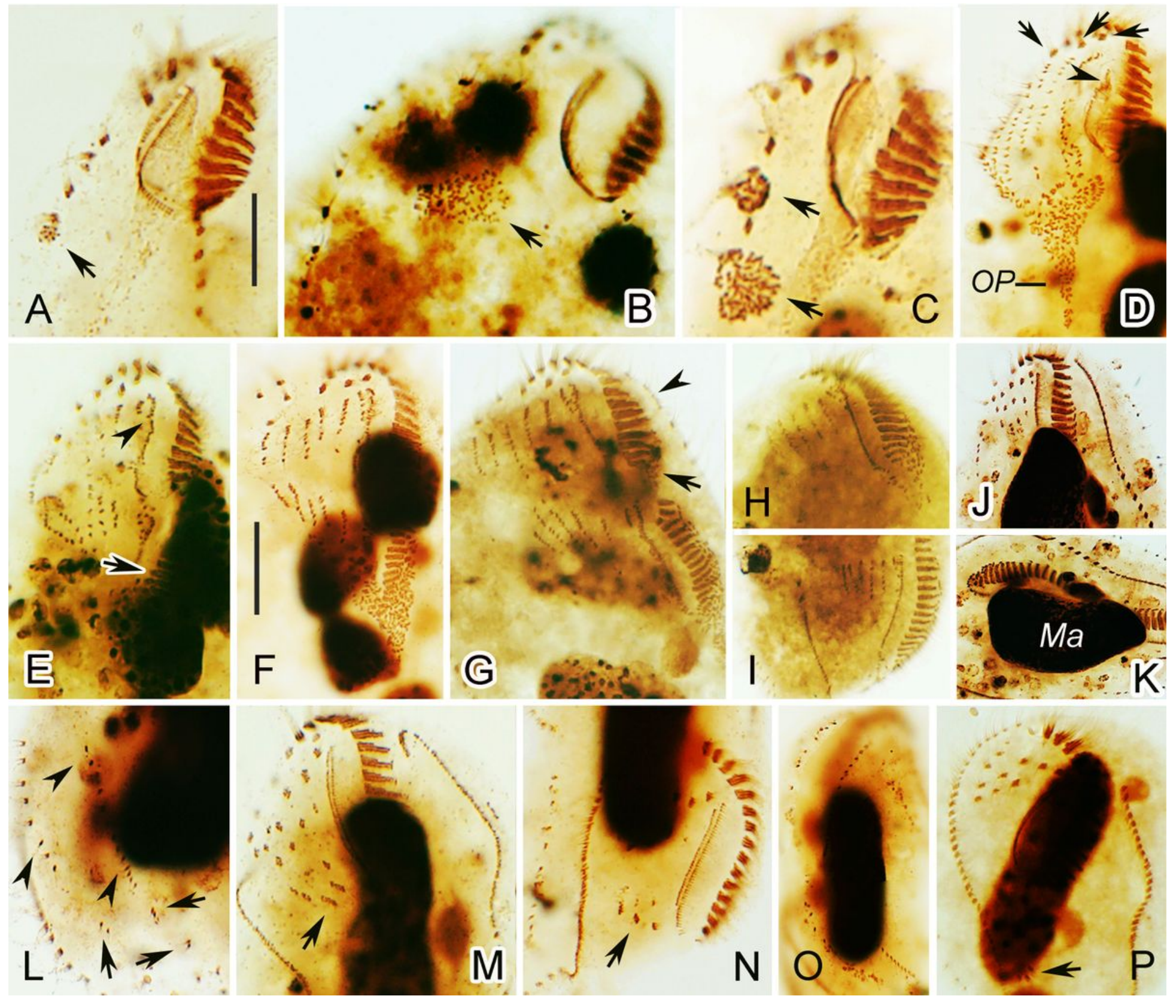

Figure 5

a-p. Photomicrographs of Parasincirra sinica n. sp. during morphogenesis (after protargol staining). (ad) Ventral views of early dividers, to indicate the oral primordium (arrows in $a-c)$, the formation of frontoventral-transverse cirral anlagen and undulating membranes starting to dedifferentiate (arrowhead). Note the old frontal cirri remain intact (arrows in d). (e, f) Ventral views of later dividers, to show the oral primordia starting to differentiate into membranelles (arrow), formation of undulating membranes anlagen in the proter (arrowhead), and frontoventral-transverse cirral anlagen starting to separate (f). ( $g-i)$ Ventral views of later dividers, to show the dedifferentiation of membranelles at the proximal end of the old adoral zone of membranelles (arrow), the intrakinetally formed anlagen for the marginal rows (arrowhead), and stretched marginal anlagen and frontoventral-transverse cirral anlagen $(h, i) .(j-l)$ Ventral $(j)$ and dorsal $(k, l)$ views of middle divider, to show frontoventral-transverse cirral anlagen differentiating into cirri (j), dorsal kineties anlagen (arrowheads), the old dorsal dikinetids 
(arrows) and the macronuclear nodules fusing into a single mass $(k) .(m, n)$ Ventral views of a late divider, arrows show transverse cirri migrating into their final positions in the opisthe $(m)$ and proter $(n)$. Note the undulating membranes anlagen longitudinally splitting into parorals and endorals. (o) Dorsal view, to show the newly formed dorsal kineties. (p) Ventral view, to demonstrate transverse cirri (arrow) migrating into their final positions. Scale bars $=15 \mu \mathrm{m}$.

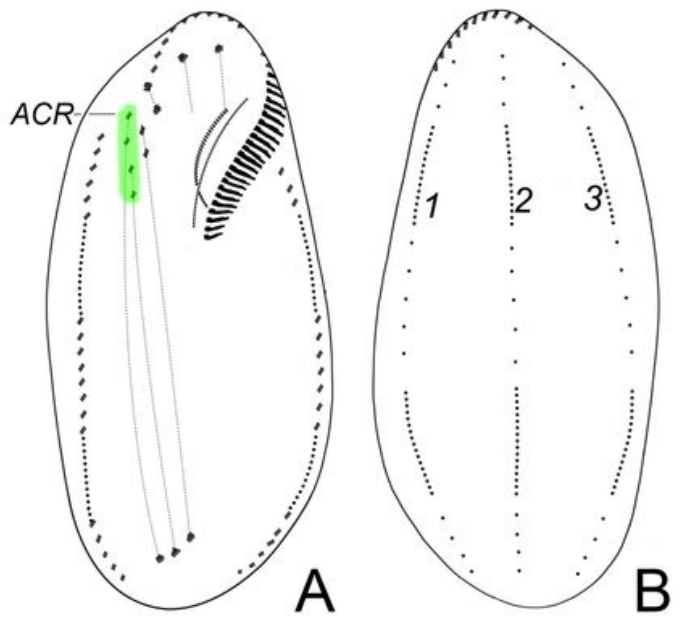

Parasincirra sinica

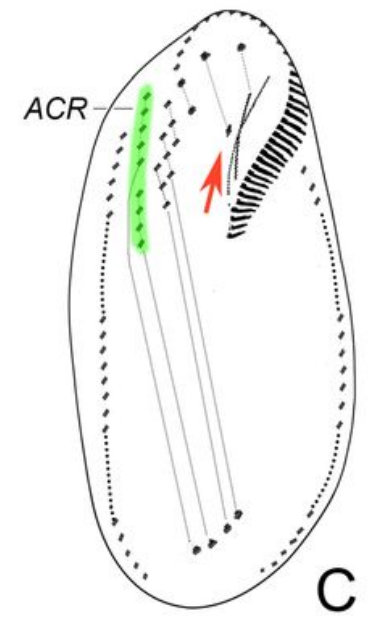

Lamtostyla salina

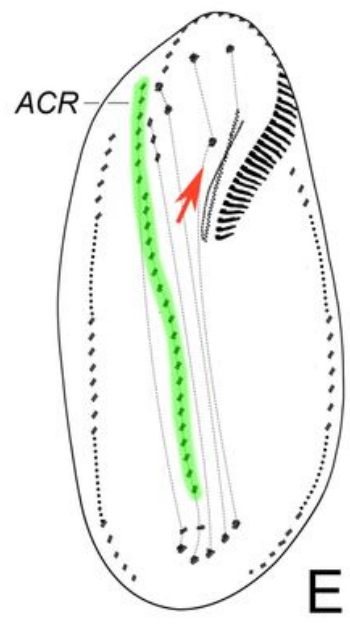

Amphisiella annulata

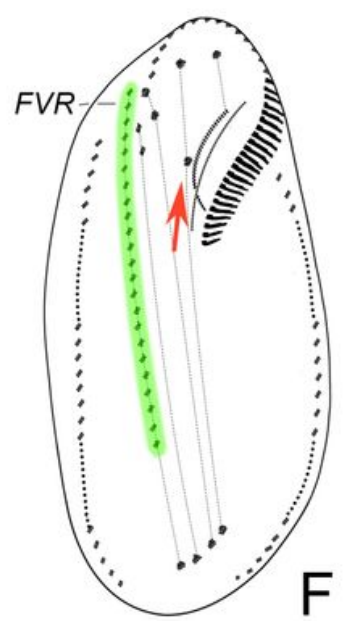

Uroleptoides longiseries

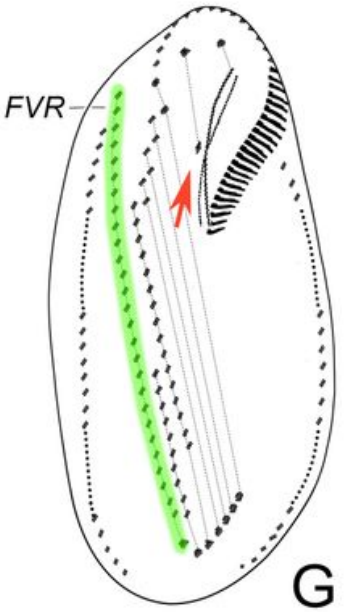

Parabistichella variabilis

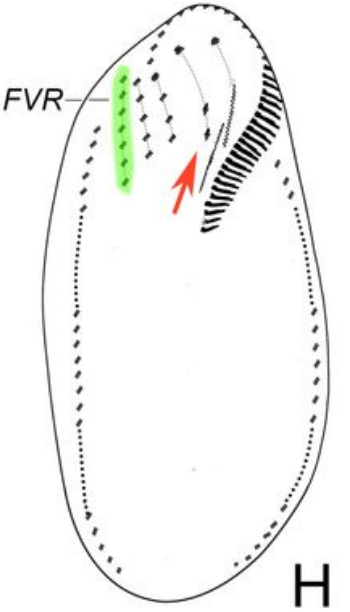

Orthoamphisiella breviseries

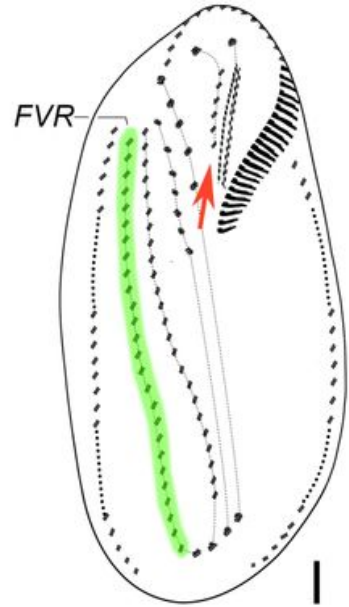

Bistichella cystiformans

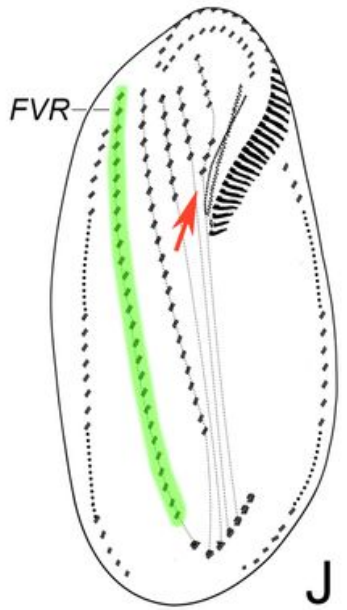

Keronopsis helluo

\section{Figure 6}

a-j. Diagram of the infraciliature, and formation patterns of ventral cirri (with dotted lines connecting cirri that develop from the same cirral streaks) (a, c, e-j) and dorsal ciliature (b, d). (a) Parasincirra sinica. (b) Parasincirra sinica, Amphisiella annulata, Uroleptoides longiseries, Parabistichella variabilis, Bistichella cystiformans and Keronopsis helluo. (c) Lamtostyla salina. (d) Lamtostyla salina and Orthoamphisiella breviseries. (e) Amphisiella annulata. (f) Uroleptoides longiseries. (g) Parabistichella variabilis. (h) Orthoamphisiella breviseries. (i) Bistichella cystiformans. (j) Keronopsis helluo [9, 29, 30, 32, 34, 36, 55]. 


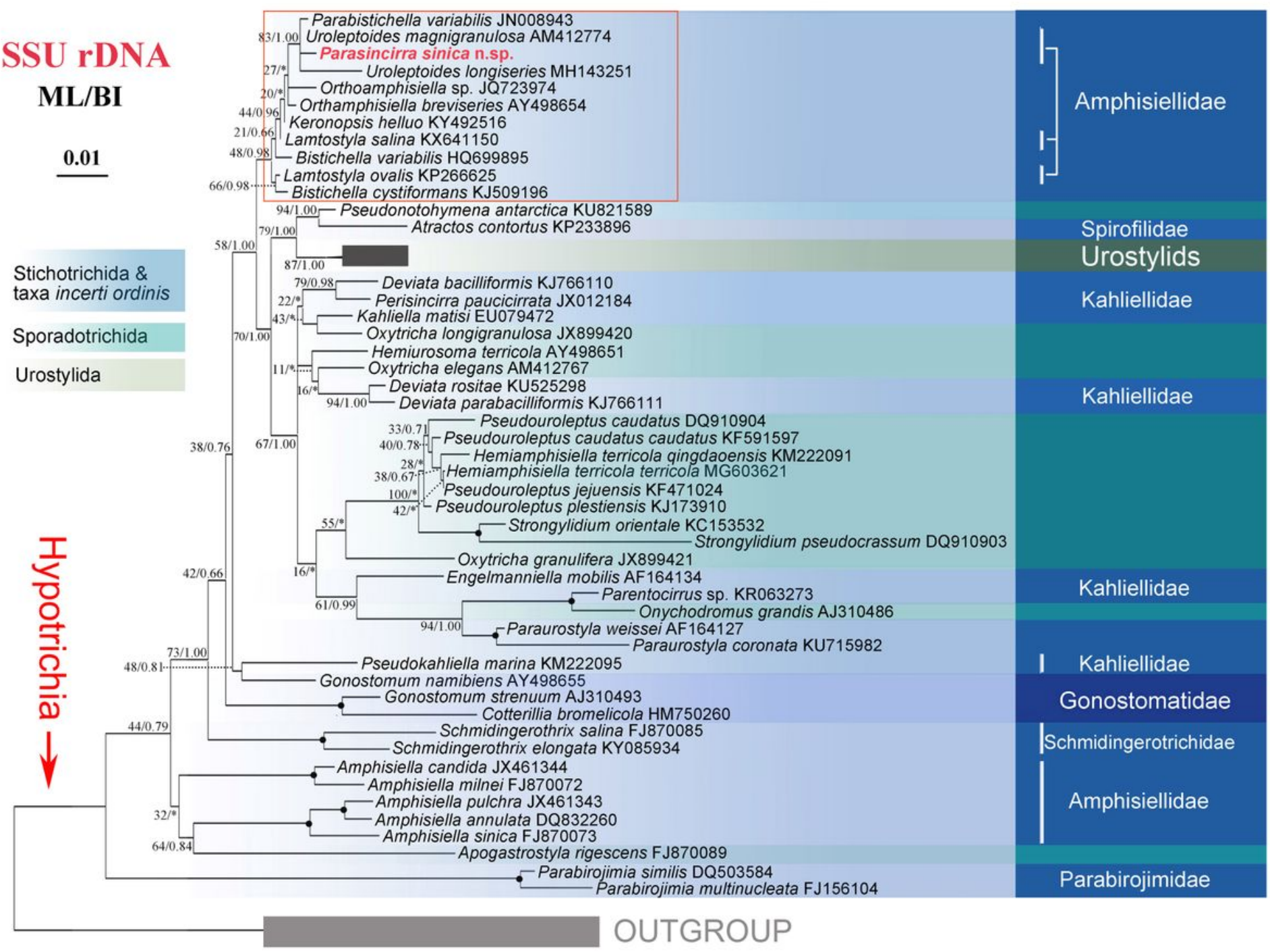

\section{Figure 7}

Maximum likelihood (ML) tree inferred from the SSU rDNA sequences showing the phylogenetic relationships of Parasincirra sinica n. sp. (in bold) and the related species (in rectangular box). Numbers near nodes are bootstrap values for maximum-likelihood and posterior probability values for Bayesian inference $(\mathrm{BI})$. "*” at nodes indicates disagreement between the two methods. Fully supported (100\%/1.00) branches are marked with solid circles. The scale bar corresponds to 0.01 expected substitutions per site. 